\title{
Teaching and Practicing Listening Skill at the Tertiary Level in Bangladesh: Prospects and Problems
}

\author{
Roksana Akter \\ Lecturer \\ Department of English \\ The Millennium University, Bangladesh \\ Email: roksanamunni8@gmail.com
}

\begin{abstract}
This paper tries to study and investigate on the topic" Teaching and Practicing Listening Skill at the Tertiary Level in Bangladesh: Prospects and Problems". The main objectives of the study is to find out to what extent teachers try to teach listening skill in Bangladesh, to what extent the learners have the scope to practice listening skill in Bangladesh. One hundred undergraduate students took part in this research. Both qualitative and quantitative methods have been used to conduct the study. Two sets of questionnaire have been developed for students as well as teachers to collect data. This paper describes the actual practice of listening skill by the teachers and the students, their behavior and attitudes and the problems they face in practicing Listening skill in Bangladesh. The methodology used for the study was a questionnaire. The results from an analysis of the questionnaire indicate that though most of the universities offer compulsory courses including listening, speaking, reading and writing, learners listening skill is not properly assessed at the tertiary level in Bangladesh. The paper concludes with a few recommendations to enhance the practice of listening skill at the tertiary level in Bangladesh.
\end{abstract}

Keywords: Teaching and Practicing, Listening Skill, Tertiary Level, Bangladesh.

\section{Introduction}

\subsection{Background of the Research}

Listening is a passive skill that means we have to listen to carefully in order to act in the different linguistics environment. Listening determines the understanding of what we hear. The linguistics signals coming through the ears are analyzed by the brain that provides a meaning to the listener. Listening is a prerequisite for speaking. Without listening there cannot be any speaking at all. The more one listens, the more one learns to speak. Infect, better listening ensures better speaking. Listening materials prepare students; they will need to do when using the language outside the classroom. It is necessary to enhance the listening skills to be proficient in any language. The listening in a second and foreign language has to be acquired through conscious efforts. Different types of materials are used in the listening classroom to enhance the listening skill. But there are several problems of adapting materials in a listening classroom of Bangladesh in case of undergraduate level of Bangladesh.

Marc Hegelson(2003) writes that the emphasis on listening begins in the late1800swith the direct method in Guin's Series and the Berlitz school. This was continued by audio lingual method where language was presented orally before being presented in the written form. With the introduction of CLT, listening was given further prominence because it was believed that learners learn through the act of communication. (Hegelson:25). Tricia Hedge feels that there is an overall emphasis on listening since "contemporary society exhibits a shift away from printed media and towards sound, and its members therefore need to develop a high level of proficiency in listening"(2001:229).

Hedge (2001) has pointed out that training second language learners in listening to English is particularly important at the tertiary level because they need to comprehend the language of classroom and lecture halls. Rahman (1999:26) points out that a student of Bangladesh gets about 1600 contact hours in English before entering the university while 1000 hours instructional time is sufficient to attain proficiency in a language. But unfortunately the students cannot interact in this foreign language even after a vast period of time spent upon this subject (ibid). Considering the Grammar Translation Method (hereafter, GTM) inadequate to the demand for producing efficient English speakers and listeners, Communicative Language Teaching (CLT) has been introduced as a tool for communication (Hamid and Jr, 2008).

\subsection{Objectives of the Research}

- To find out the real scenario of teaching and practicing listening.

- To what extent teachers try to teach listening skill in Bangladesh.

- To what extent learners has the scope to practice listening skill in Bangladesh. 


\subsection{Statement of the Research Problem}

As Bangladeshi students are not taught listening skills at their secondary and higher secondary levels, using native contexts at the beginning of the tertiary level will create problems for them (Alam and Sinha, 2009:43)

Alam and Sinha (2009:21) have mentioned that most of the teaching at tertiary level is done by lectures and classes in most of the universities in our country are conducted in English. Besides, teachers having degrees from native speech countries may have different accents. As a result, they may deliver lectures in English with foreign accent. Students especially from Bangla medium sometimes face problems in understanding such lectures. Only 14\% students of tertiary level are from English medium background (Jahan, 2008:162). Most of the students are from Bangla medium with weak English language competence (ibid).

Students facing problems in the classroom may also face difficulty in understanding the foreign programmes, but as learners of a foreign language they have to spend more time in receiving messages from radio, television announcements and of many other situations (Littlewood, 1981).

\subsection{Significance of the Research}

Listening is key to all effective communication, without the ability to listen effectively message are easily misunderstood-communication breaks down and the sender of the message can easily become frustrated and irritated.

Alam and Sinha (2009:32) have pointed out that tertiary level students have to listen to comprehend class lectures, to take notes, to carry out tasks and to interact with teachers and peers. Listening also plays a life-long role in the process of productive communication (ibid). Hedge (2001 in Alam and Sinha, 2009:20) says that to establish oneself in this sound system based society one must develop a high level of proficiency in listening.

Venkateswaran (1995:74) the purpose of teaching a language is to enable the learners to communicate in the target language. He proposes that every second of every language class must be used to equip students with the language skills according to their need. As listening is a prerequisite to communication it requires training (Alam and Sinha, 2009:22). Venkateswaran (1995:76) says that students must be trained to perceive syntactic groupings and also to produce meaningful longer segments from what they hear. So, listening must be accompanied by some activities through which students can demonstrate their comprehension. It is also observed by Sadat and Alam (2007:65) that culture and contexts greatly influence learning. So, we need contextual listening as well as contextual learning.

\subsection{Research Questions}

The study addresses the following central research questions:

- What is the real scenario of teaching and practicing listening?

- What extent teacher tries to teach listening skill in Bangladesh?

- What extent learner has the scope to practice listening skill in Bangladesh?

\section{Literature Review}

\subsection{Listening}

"Listening is a skill and any help we can give students in performing that skill will help them to be better listeners" (Harmar, 1998:98). Venkateswaran (1995:76) says that listening is an invisible mental process and also is an interactive process where the listeners work with their background knowledge and also with the current knowledge.

Thus listening does not mean hearing only, but it also involves comprehension and at the same time acts as a bridge in the learning process (Abedin et al., 2009).

\subsection{Significance of Listening Skill}

Richards (2008:3) says that "by providing aural input listening accelerates language learning". Language learning is dependent on listening and it can connect the learners directly to the target language (Peterson, 2001:87). By listening to a regular academic program of this skill learner's vocabulary and idioms can be enriched by developing their cultural appreciation which facilitates their interpretation of the new language (ibid). So, language teachers must help the students to become good listeners because listening is also the basis of cognitive development (Saha, 2008:205). Long (1987:921)) says that," teachers are eager to develop students' oral proficiency". Teaching speaking skill in ELT has become a fashion than the teaching of listening skill (Richards, 2008). But in general, speaking cannot be separated from listening. Long (1987) has considered the listening skill as the other half of oral proficiency. For successful conversation we need to develop 'Conversational listening skill' (Nunan, 1989, 32).

Communication requires sender, message and also receiver (Richards, Platt and Weber, 1985:48). To be communicatively competent we have to respond to various speech acts (ibid) which involve listening. Venkateswaran (1995:76) says that for effective listening in communicative situation, understanding the main message is necessary. CLT approach aims to make the learners communicatively competent (Barman, Sultana and Basu, 2006:254) because "communicative ability is the goal of foreign language learning" (Littlewood, 1981:2). "Language is a system for the expression of meaning" and it is not only the combination of grammatical rules but also has functions and communicative meaning (Richards and Rodgers, 2001: 161). Littlewood (1981) mentions that 
the listener will have to extract the meaning with the existing noise distance and unclean sound and the receiver must understand the everyday speech which contains false starts, hesitations (ibid).

\subsection{Practice of Listening Skill in General}

Long's study (in Long, 1987) shows that only $2 \%$ of total classroom time is spent for the development of listening skill. Long (1987:921) mentions that though the awareness is growing the teachers are not giving full attention to the development of their students' listening skill. Wang (2008) points out that in teaching English in the EFL contexts of Japan, Korea and China listening skill is ignored even in the modern EFL teaching process.

\subsection{Bangladeshi Context}

Maniruzzaman (2002:134) identifies listening as a challenging skill for the foreign language learners because this skill requires substantial endeavors by the learners. In case of acquiring our mother tongue we listen and speak, and then learn reading and writing but it is totally opposite when we are learning English — reading and writing and then occasionally listening and speaking (ibid). The author claims that this is the reason why Bangladeshi students face difficulty in case of listening English and they need to invest sufficient endeavors to acquire this skill. But the true fact is that students are never given that chance, because as Saha (2008:193) explains that in the schools, colleges and even in the university education Bangladeshi learners are never directed how to listen.

As the students of Bangladesh are never exposed to listening they fail to manage any kind of interaction (Bhattacharjee, (2008:18). Alam and Sinha (2009:20) claim that the neglect of listening skill in our language classes makes the learners weak in the spoken language also. It has been found that in most of the language courses in our country listening is never taught (Saha, 2008).

\subsection{English Language Teaching Policy in Bangladesh}

Das (2009:29) says that in the British India it was the English language which ensured high status and position in the society. Since learning English was very lucrative the people were in a competitive mood to learn the "King's English" (ibid). Das points out that in Pakistan English was taught and learned as a second language. English was the compulsory subject in secondary and higher secondary levels and it was the medium of instruction at the tertiary levels (Rahman, 1999:14). Ara (2009:10) says that after the emergence of Bangladesh English learning suffered much. As English got the status of foreign language this had a consequence in all the fields especially in the education sector (Rahman, 1999:13). Curriculums of English from primary to degree levels always keep changing with the shift of the governments (Das, 2009:49). Rahman (1999:13) says that teaching of English got inadequate attention at lower levels and learners were going to the tertiary levels with weak command of English while textbooks and lectures were in English at this level. As a result students fail to read the books and express their views in

English (ibid). Under these circumstances Rahman (1999:14) says that English has given 'a new status' in Bangladesh. Though the necessity of learning was felt, in the first official document of language teaching policy Bangla was given the medium of instruction at all levels of education and only for the sake of reality English was made a compulsory subject from class six to twelve (Das, 2009:39). But this policy ignored the teaching of English at tertiary levels (ibid).

In 1976, to assess the ELT situation in Bangladesh an English Language Teaching Task Force was set up by the Ministry of Education (Das, 2009:46). This task identified some reasons responsible for the poor teaching condition of Bangladesh that are given below.

- Lack of helpful textbooks

- Acute shortage of qualified teachers of English at all levels of education

- Big size of the class

- Defective examination system

Das (2009) identified that this task force did not report anything about the growing number of English medium schools.

In 1990, a survey report of National Curriculum and Textbook Board (NCTB) gave a frustrating picture of English proficiency among learners because it found that according to the syllabus and textbooks majority of the students are not achieving satisfactory levels of proficiency in learning the English language (in Ara, 2009).

Until 1980 English was taught as a compulsory subject in BA Honors and Pass Course but it was discontinued and in 1992 the Bangladesh Government passed an act to reintroduce English as a compulsory subject for all BA Honors and Pass Course students (Rahman, 1999:19). Though this act was supposed to be implemented from 1994-1995 session, even the 1995-1996 session did not ensure it (ibid). The National Committee on

Education Policy 1997 (in Das, 2009) proposed four year degree course and one year master's course at the tertiary level.

Since the independence of Bangladesh many policies keep changing regarding the teaching and learning of English (Ara, 2009:10). Since 1991 NCTB has also been trying to improve the quality of English language teaching in 
Bangladesh but unfortunately none of the policies helped the students to develop their proficiency in the English language (ibid). Jahan (2008:155) says that after learning English for 13 to 15 years the students of Bangladesh cannot communicate in English. In this regard Bhattacharjee (2008:19) blames the recurrent changes in the curriculum and over emphasis on Bangla.

\subsection{CLT and Listening skill in Bangladesh}

Since the rule of the British empire GTM had been practiced for a long time in the EFL context of Bangladesh (Hasan and Akand, 2009:45). But this method failed to enable the students to communicate both in oral and written English (Hamid and Jr, 2008). Realizing the failure of GTM, in 1998, English Language Teaching Improvement Project (ELTIP) was established to improve the quality of ELT by using the CLT approach (ibid). Hamid and Jr (2008) informs that the books which ELTIP produced are supposed to follow the techniques and activities of CLT approach and their basic principle is to help the learners to learn the English language in an interactive mood by using all the four skills - listening, speaking, reading and writing. In Bangladesh, the change from GTM to the CLT approach since 1990's has been termed as 'paradigm shift' by Alam and Sinha (2009:19). Though the teachers are supposed to teach following the CLT, unfortunately it is not done (ibid).

\subsection{Teaching Listening Skill}

Ur (1984) suggests encouraging the learners to decode from the information by using his common sense and native language for his understanding. Because comprehension requires the simultaneous interaction of bottom up and top down processing (Silberstein, 1994:7). In bottom up processing input is depicted against the reader's previous knowledge and top down processing of occurs when prior knowledge is used to make predictions about the given input (ibid). Silberstein (1994) suggests that activities that help the students in using background knowledge facilitate the comprehension.

According to Morely (2001) in the top down processing of listening the listener's ability is involved to use prior information to understand the heard language. The bottom up process helps the listener to give close attention to every detail of the language input and bottom up mood assists to listen as well as grasp the sounds of words, grammatical relationships and lexical meaning (ibid).

It is also suggested by Ur (1984) that exercises that encourages a relaxed and holistic approach help the foreign learners to perceive meaning from the input that is heard. Nunan (1999) suggests few characteristics for a listening course like explicit listening goals, use of authentic materials, schema building tasks, strategies for effective listening and opportunities for the learners to practice in the classroom.

\section{Research Methodology}

\subsection{Research Design}

This research is quantitative and qualitative in nature. The purpose of the study is to reveal the ignorance towards listening skill and also to generate awareness for the implementation of this skill. The investigation was conducted through close ended to 100 students and 10 teachers at three different universities. The researcher has to collect data from Comilla University, Britannia University and Victoria Collage, Comilla (Under National University).

\subsection{Setting}

The study was conducted in the formal setting of the classroom. Because of the formal setting it was necessary to make the students free to get the actual information. Though the data was collected from the classroom, there was an effort to make the atmosphere relaxed for the students. Teachers were interviewed in the university setting at their appointed time.

\subsection{Instrument}

For collecting data questionnaire was given to the students. The questionnaire (Appendix-A) comprised ten close ended questions. Questions 1, 2 and 3 were asked to collect general information about the teaching procedure of the class as well as of the university. The forth question was given to know about the student's understanding level. The fifth question was used to understand whether the students are aware about listening skills or not. Questions 6 and 9 were asked to know how much interactive the classes are. Questions 7 and 8 were asked to collect the information about the context and material of the courses. The last question provided the students the chance to express their opinion. All these questions are directly related to the central research question 1 and to some extent these are also linked to the central research question 2.

\subsection{Data Collection Procedure}

It took 15 to 20 minutes to conduct the survey. As the teachers were requested earlier the survey was done in the absence of the teachers at the beginning or at the end of the classes. After entering into the classroom instruction was given in English. After the introductory part the questionnaire was distributed among all the present students with proper guidance. The students were assured that their identities would be kept hidden. Here, dichotomous questions have been used for collecting data from the teachers and students by the researcher. 


\section{Data analysis}

\subsection{Analysis of the student's questionnaires}

100 students have been selected from three classes to collect data. 10 questionnaires have been served to the students by the researcher for collecting correct information.

Table -1: Students' questionnaire analysis

\begin{tabular}{|c|c|c|c|c|}
\hline $\begin{array}{l}\text { SL } \\
\text { NO }\end{array}$ & Questions & Results & & \\
\hline \multirow[t]{2}{*}{1.} & \multirow[t]{2}{*}{ What is the medium of instruction in your English class? } & English & Bangla & $\begin{array}{lr}\text { Mixure } & \text { of } \\
\text { English and } \\
\text { Bangla }\end{array}$ \\
\hline & & $48 \%$ & $0 \%$ & $52 \%$ \\
\hline \multirow[t]{2}{*}{2.} & \multirow[t]{2}{*}{ Has the university offered any specific listening course to you? } & Yes & & No \\
\hline & & $10 \%$ & & $90 \%$ \\
\hline 3. & $\begin{array}{l}\text { Is there any mark allocated for listening skills in your English } \\
\text { outlines? }\end{array}$ & $30 \%$ & & $70 \%$ \\
\hline 4. & Do you understand English programmes? & $49 \%$ & & $51 \%$ \\
\hline 5. & Do you need practice to develop your listening skill? & $97 \%$ & & $3 \%$ \\
\hline 6. & $\begin{array}{l}\text { Are there any activities/activity done in your English classes } \\
\text { for listening skill? }\end{array}$ & $31 \%$ & & $69 \%$ \\
\hline 7. & $\begin{array}{l}\text { Do you think that the content of your classroom activities is } \\
\text { from Bangladeshi context? }\end{array}$ & $38 \%$ & & $62 \%$ \\
\hline 8. & Have you found the material interesting? & $51 \%$ & & $49 \%$ \\
\hline 9. & $\begin{array}{l}\text { Are you motivated to take part in presentation/role play/group } \\
\text { work/pair work in your English classroom? }\end{array}$ & $25 \%$ & & $75 \%$ \\
\hline 10. & $\begin{array}{l}\text { Do you prefer specific course for the development of your } \\
\text { listening skill? }\end{array}$ & $90 \%$ & & $10 \%$ \\
\hline
\end{tabular}

In response to the question 1 (Table- A), it has been found that 52\% students answered that the medium of instruction at their universities is a mixture of English and Bangla while $48 \%$ students replied that the medium of instruction is solely English.

In response to the question no 2, $90 \%$ students said that their universities do not offer any specific course on listening. Only 10\% Students answered that a specific course named "listening and speaking" is offered positively. In answer to the question no 3,70\% Students denied the allocation of marks in their course outlines. 30\%students informed that since very few marks is allocated teachers give little attention and thus it is not helping to improve this (listening) skill.

The result of the question 4 indicates that $49 \%$ students to some extent understand the spoken English used in English programmes. $51 \%$ students mentioned that they do not understand English programmes at all while some students said that they understand.

From question 5, it has been found that $97 \%$ students feel the need to practice to develop their listening skills. The rest $3 \%$ students said no.

It is evident from question 6 that specific listening activities are not being done in the universities because $69 \%$ students said that no activity was practiced in the class for this skill while $31 \%$ students said that it was.

In response to the question 7,38\% students replied that sometimes the materials of their lessons are taken from Bangladeshi context and $62 \%$ students informed that the content of their lessons are always foreign.

The result of the question 8 indicates that students are not motivated to learn the English language. 51\%students informed that the materials used in the classroom are not always interesting. 49\%students blame the teaching style which cannot make the lessons interesting.

It is evident from question 9,75\% students are never involved in any kind of activities like presentation, pair work, role play and group work. Only $25 \%$ students always participate in the classroom activities 
In answer to the question 10, almost all the students (90\%) want their universities to offer specific listening course. Some students said that self-practice is enough to develop English listening skills while a few mentioned that marks allocation is needed.

\subsection{Analysis of the Teacher's Questionnaires}

The researcher used questionnaire to find out data from participant teachers. The questionnaire was distributed to ten English teachers of two universities (Britannia University and Commila University) of Comilla. The teacher's questionnaires included 10 questions with fixed alternatives.

Table-2: teachers' questionnaire analysis

\begin{tabular}{|c|c|c|c|}
\hline $\begin{array}{l}\text { SL } \\
\text { NO }\end{array}$ & Questions & Resu & \\
\hline \multirow[t]{2}{*}{1.} & \multirow{2}{*}{$\begin{array}{l}\text { Do you use mixture of English and Bangla medium of } \\
\text { instruction in your English class? }\end{array}$} & Yes & No \\
\hline & & $51 \%$ & $49 \%$ \\
\hline 2. & $\begin{array}{l}\text { Do you think that the universities offer any specific listening } \\
\text { course to the students? }\end{array}$ & $25 \%$ & $75 \%$ \\
\hline 3. & $\begin{array}{l}\text { Is there any mark allocated for listening skills in your English } \\
\text { outlines? }\end{array}$ & $30 \%$ & $70 \%$ \\
\hline 4. & Do you think that students understand English programmes? & $60 \%$ & $40 \%$ \\
\hline 5. & $\begin{array}{l}\text { Do you think that students need to practice to develop their } \\
\text { listening skill? }\end{array}$ & $99 \%$ & $1 \%$ \\
\hline 6. & $\begin{array}{l}\text { Are there any activities/activity done in your English classes } \\
\text { for listening skill? }\end{array}$ & $40 \%$ & $60 \%$ \\
\hline 7. & $\begin{array}{l}\text { Do you think that the content of your classroom activities is } \\
\text { from Bangladeshi context? }\end{array}$ & $38 \%$ & $62 \%$ \\
\hline 8. & Do you think that students find the material interesting? & $49 \%$ & $51 \%$ \\
\hline 9. & $\begin{array}{l}\text { Do you motivate your students to take part in presentation/role } \\
\text { play/group work/pair work in your English classroom? }\end{array}$ & $51 \%$ & $49 \%$ \\
\hline 10. & $\begin{array}{l}\text { Do you prefer specific listening course for the development of } \\
\text { your listening skill? }\end{array}$ & $90 \%$ & $10 \%$ \\
\hline
\end{tabular}

In response to the question 1 (Table- B), it has been found that $51 \%$ teachers answered that the medium of instruction at their universities is a mixture of English and Bangla while 49\%teachers replied that the medium of instruction is solely English.

In response to the question no 2, 75\%teachers said that their universities do not offer any specific course on listening. $25 \%$ teachers of only one university answered yes.

$70 \%$ teachers informed that since very few marks is allocated teachers give little attention and thus it is not helping to improve this (listening) skill. It has also been found that each and every student does not get the chance to practice listening.

The result of the question 4 indicates that $60 \%$ teachers think that students to some extent understand the spoken English used in English programmes. $40 \%$ teachers said that students do not understand English programmes at all. From question 5 , it has been found that $99 \%$ of the teachers feel that students need to practice to develop students listening skills. Only $1 \%$ teachers said no.

It is evident from question 6 that specific listening activities are not being done in the universities because $60 \%$ teachers said that no activity was practiced in the class for this skill while $40 \%$ teachers said that it was.

In response to the question $738 \%$ teachers replied that sometimes the materials of their lessons are taken from Bangladeshi context and 62\% teachers informed that the content of their lessons are always foreign.

The result of the question 8 indicates that $49 \%$ teachers said that they motivated students to learn the English language. The rest $51 \%$ teachers do not do that.

It is evident from question 9 that $51 \%$ teachers said that some students are sometimes involved in some kind of activities like presentation, pair work, role play and group work. Other $49 \%$ teachers said no to the answer.

In answer to the question 10, almost all the students (90\%) want their universities to offer specific listening course. Some students said that self-practice is enough to develop English listening skills while a few mentioned that marks allocation is needed. 


\section{Discussion}

\subsection{Discussion in Terms of Students' Perspective}

In response to the question 1(Table- A), it has been found that most of the students answered that the medium of instruction at their universities is a mixture of English and Bangla while other students replied that the medium of instruction is solely English. Technically speaking the medium of instruction at universities is English but the teachers use Bengali with English because the first year undergraduate students do not understand the English lecture since most of them have been shifted from Bengali to English medium. The present result demonstrates that teachers use Bangla with English to make the students understand specially the difficult English terms and vocabularies. Few students also confessed that they are weak in understanding English and mixture of mother tongue and the foreign language makes it easy for them to understand. It was also informed by the students that Bangla is used by the teachers to make the students easy and comfortable. The data also shows that a very few students support the solely English instruction.

In response to the question no 2, most of the students said that their universities do not offer any specific course on listening. Some Students of only one university answered that a specific course named "listening and speaking" is offered positively in this regard. This finding suggests the negligence of listening skills by the private universities. According to the students' information sometimes teachers give ideas to develop the students' listening skills. It has also been found that though any particular listening course is hardly offered the students still get chance to practice it by using the sound system. But again the logistic support is not sufficient and modern; as a result, learners do not feel interested.

Students denied the allocation of marks in their course outlines. Some students informed that since very few marks is allocated teachers give little attention and thus it is not helping to improve this (listening) skill. It has also been found that each and every student does not get the chance to practice listening.

The result of the question 4 indicates that students to some extent understand the spoken English used in English programmes. A few students mentioned that they do not understand English programmes at all while some students said that they understand. The reasons for not understanding are intonation, stress, accent, dialect, the fast space of the native speakers and unfamiliar words. Few students informed that their teachers motivate them to watch and listen to English programmes. Some students mentioned that if they listen attentively and carefully then they can understand.

From question 5, it has been found that majority of the students feel the need to practice to develop their listening skills. The finding shows that students are aware of the importance of developing their listening skills. The reasons for developing their listening skills are to understand the foreign accents and to communicate in English. One student mentioned that the schools and colleges do not give the opportunity to practice English listening skills so the university must give the chance. Another student also said that if there is class for listening skills then there will be homework, which can create pressure to practice at home; he further mentioned that only self- motivation is not enough to encourage oneself to practice.

It is evident from question 6 that specific listening activities are not being done in the universities because most of the students said that no activity was practiced in the class for this skill while some students said that it was. In terms of the background information the students who have answered positively mentioned that they have to answer after hearing the cassette player and watching the piece of movies. Mostly they work in groups. In this regard one has mentioned the name of an activity "Planning a Party". The students who gave negative response wrote that their teachers advise them to watch and listen to the English programmes in radio and television.

In response to the question 7 most of the students replied that sometimes the materials of their lessons are taken from Bangladeshi context and equally the same number of students informed that the content of their lessons are always foreign. So it is evident that contextualized materials are not frequently used in the teaching of English listening skills. Some students mentioned that their teachers talk about the Bangladeshi incidents to make the students understand. One has mentioned that teachers think of USA and UK contexts as their idol. Few students have the realization that Bangladeshi context will help to know Bangladesh as well as the English context. At the same time some students consider the use of Bangladeshi context unnecessary in the English classroom. It is also found that a few students are familiar with the use of Bangla magazines and Indian books and their teachers also let them to relate the foreign topics with their culture.

The result of the question 8 indicates that students are not motivated to learn the English language. Most of the students informed that the materials used in the classroom are not always interesting. Some students blame the teaching style which cannot make the lessons interesting. The students further mentioned that the lessons and texts which are easy and related to the Bangladeshi context help them to feel comfortable. It has been found that the texts are interesting when the teachers help the students to understand the concepts in the texts. 
It is evident from question 9 some students are never involved in any kind of activities like presentation, pair work, role play and group work. Though some other students always participate in the classroom activities, it is also clear that most of the students hardly get chance to take part in the classroom activities.

Reasons for not being involved in the classroom activities are time constraint, lack of interest/ motivation, shyness, hesitation, tension and fear of being ridiculed. The finding also suggests that the extroverts are the ones who are constantly participating in the classroom activities. Students also mentioned that if they work in groups they can discuss freely.

In answer to the question ten, almost all the students want their universities to offer specific listening course. Some students said that self-practice is enough to develop English listening skills while a few mentioned that marks allocation is needed.

\subsection{Discussion in Terms of Teacher's Perspective}

In response to the question 1(Table- B), it has been found that most of the teachers answered that the medium of instruction at their universities is a mixture of English and Bangla while other teachers replied that the medium of instruction is solely English. Technically speaking the medium of instruction at the private universities is English but the teachers use Bengali with English because the first year undergraduate students do not understand the English lecture since most of them have been shifted from Bengali to English medium.

In response to the question no 2, most of the teachers said that their universities do not offer any specific course on listening. Some teachers of only one university answered that a specific course named "listening and speaking" is offered positively in this regard. This finding suggests the negligence of listening skills by universities. Sometimes teachers give ideas to develop the students' listening skills. It has also been found that though any particular listening course is hardly offered the students still get chance to practice it by using the sound system. But again the logistic support is not sufficient and modern; as a result, learners do not feel interested.

Some teachers informed that since very few marks is allocated teachers give little attention and thus it is not helping to improve this (listening) skill. It has also been found that each and every student does not get the chance to practice listening.

The result of the question 4 indicates that most of the teachers think that students to some extent understand the spoken English used in English programmes. A few students do not understand English programmes at all. The reasons for not understanding are intonation, stress, accent, dialect, the fast space of the native speakers and unfamiliar words. Teachers mentioned that if they listen attentively and carefully then they can understand.

From question 5, it has been found that majority of the teachers feel the need to practice to develop students listening skills. They also think that students are aware of the importance of developing their listening skills. The reasons for developing their listening skills are to understand the foreign accents and to communicate in English.

It is evident from question 6 that specific listening activities are not being done in the universities because most of the teachers said that no activity was practiced in the class for this skill while some teachers said that it was.

In response to the question 7 most of the teachers replied that sometimes the materials of their lessons are taken from Bangladeshi context and equally the same number of teachers informed that the content of their lessons are always foreign. So it is evident that contextualized materials are not frequently used in the teaching of English listening skills.

The result of the question 8 indicates that students are not motivated to learn the English language. Most of the teachers informed that the materials used in the classroom are not always interesting to the students.

It is evident from question 9 that most of the teachers said that some students are sometimes involved in some kind of activities like presentation, pair work, role play and group work.

In answer to the question ten, (Table- 2) almost all the students want their universities to offer specific listening course. Some students said that self-practice is enough to develop English listening skills while a few mentioned that marks allocation is needed.

\section{Conclusion and Recommendation}

\subsection{Conclusion}

In Bangladesh listening skill is always not given so much importance throughout the whole academic life of a student (ibid). Even at the tertiary level this skill is not taught. So, the present study aimed to focus on how much listening skills are taught by the teachers and practiced by the students at the universities and to determine the types of strategies that are needed to develop English listening skills. To reach the goal the study collected data from 100 students and 10teachers of 3 universities.

Based on the findings it seems that most of the universities are not well equipped to provide the chance of adequate practice of listening skills. Inappropriate syllabus and insufficient logistic support do not permit teachers to practice the listening skills in the classrooms. So, language teachers hardly give attention towards this skill. 
Limited resources and logistic support give the learners hardly any exposure to the listening skills. The few learners who are exposed to these activities are being taught with the foreign culture because teachers do not focus on the local materials. While contextual background is necessary for understanding, lack of schematic knowledge dispels the learners' interest and participation and as a result language learning does not progress.

The findings of the study seem to suggest that the Basic English or Fundamentals of English courses of universities are incomplete without practicing listening skill. Without this skill student can be found inefficient in English language. At the same time the findings of the study suggests that the use of appropriate strategies can improve the learners' listening skills as well as knowledge of English. Based on the findings the strategies are- a language class should not exceed 15-20 students, marks should be allocated and listening activities need to be practiced by using argumentative and authentic topics.

Quader's (1998) findings explain that in Bangladesh students of all levels face difficulty mainly with listening skill which shows that their low proficiency make it difficult for them to understand the language. It is only because our students are never exposed to the formal listening (Bhattacharjee, 2008).

\subsection{Recommendation}

Based on the findings it may be mentioned that effective and ideal English language courses need to be introduced to help the learners to be better listeners. Some recommendation for effective listening at the tertiary level of universities can be considered:

- Effective materials should be produced by the teachers to make the learning enjoyable and in this regard teachers need some expertise to prepare those;

- Teachers need to be trained to take the language classes;

- Syllabus should specify the listening skills and university authorities need to provide the necessary logistic support for the teaching of this skill

- Outlines should be prepared by allocating marks for the listening skills

- Teachers need to be mentally prepared to teach the listening activities with the existing constraints;

- Materials should be used according to the learners' level and they should be given the scope to use their background knowledge to connect with the materials;

- Exposure to sufficient English speech is necessary and in this regard conversational clubs can be established;

- Curiosity and interest should be aroused among the learners to involve them in the listening activities;

\section{References}

Abedin, M. M., Majlish, S. H. K. and Akter, S. (2009). Listening Skill at Tertiary Level: A Reflection. The Dhaka University Journal of Linguistic. Vol. 2, No. 3, 69-90.

Alam, Z. and Sinha, B. S. (2009). Developing Listening Skills for Tertiary Level Learners. The Dhaka University Journal of Linguistics. Vol. 2, No. 3, 19-52.

Akter, Z. (2006). Redefining 'Communicative Competence' in Teaching English as a Foreign Language in Bangladesh.Harvest: Jahangirnagar Studies in Language and Literature. Vol. 21, 13-22.

Ara, S. (2009). The contribnution of the communicative language teaching approach to teaching writing in the English classroom. Harvest: Jahangirnagar Studies in Language and Literature, Vol. 24, 9-26.

Bhattacharjee, N. (2008). Developing Speaking Skills at Secondary and Higher Secondary Levels: Problems and Few Recommendations. Stamford Journal of English, Vol. 4, 14-27.

Barman, D. B., Sultana, Z. and Basu, B. L. (2006). ELT Theory and Practice. Bangladesh: Friends Book Corner.

Chand, R. K (2007). Same Size Doesn't Fit All: Insights from Research on Listening Skills at the University of the South Pacific (USP).The International Review of Research in Open and Distance Learning. Vol. 8, No. 3.

Das, B. B. (2009). The Reports of Education Commissions and English in Bangladesh. Harvest: Jahangirnagar Studies in Language and Literature, Vol. 24, 27- 51.

Ellis, R. (1985). Understanding Second Language Acquisition. Oxford: Oxford University Press.

Ellis, R. (1992). Second Language Acquisition and Language Pedagogy. Clevedon: Multilingual Matters.

Haque, M. S. (2009). Offering World Class Higher Education. The Daily Star. 5 and 16.

Hasan, K. and Akhand, M. M. (2009). Challenges and Suitability of TESL at the College Level in Bangladeshi Context. Journal of NELTA. Vol. 2, No. 1-2, 45-54.

Hamid, M. O. and Jr, R. B. B. (2008). Will CLT bail out the bogged down ELT in Bangladesh? English Today. Vol. 24 , No. 3, 16-24

Harmar, J. (1998). How to Teach English. London: Longman

Jahan, A. (2008). Teaching Speaking Skills at Tertiary level in Bangladesh: An Empirical Investigation. Daffodil International University Journal of Business and Economics. Vol. 3, No. 1, 55-171.

Kashen, S. (1985). The Input Hypothesis: Issues and Implications. Cambridge University Press. 
Krashen, S. (1981). Second Language Acquisition and Learning.London: Pergamon.

Khan, H. R. (2005). Teaching English in Primary Schools: Pros and Cons. Bangladesh Education Journal. Vol. 4, No. 1, 25-31.

Littlewood, W. (1981). Communicative Language Teaching. United Kingdom: Cambridge University Press.

Long, R. D. (1987). Listening Comprehension: Need and Neglect. Hispania. Vol. 70, No. 4, 1921-1928.

Morely, J. (2001). Aural Comprehension Instruction Principles and Practices. In M. C. Murcia (Ed), Teaching English as a second or foreign Language. (3rd ed. pp 69-85). USA: Heinle\&Heinle.

Maniruzzaman, D. M. (2002). Basic English Language Skills. Dhaka: Friends Book Corner.

Mannan, A. (2009, December 30). Private Universities-A Half Glass Full. The Daily Star. 4.

Miyan, M. A. (2009, December 30). Creation of Knowledge Conductive to Development. The Daily Star. 6.

Nunan, D. (1989). Designing Tasks for the Communicative Classroom. Cambridge: Cambridge University Press.

Nunan, D. (1999). Second Language Teaching and Learning. USA: Heinle and Heinle.

National Education Policy 2010. Ministry of Education.Dhaka: Jubili Publications.

Pahuja, N. P. (1995). Teaching of English. New Delhi: Anmol Publications.

Peterson, P. W. (2001). Skills and Strategies for Proficient Listening. In M. C. Murcia (Ed), Teaching English as a second or foreign Language. (3rd ed. pp 87- 100). USA: Heinle\&Heinle.

Quader, A. D. D. (1998). Students' perception of difficulty in Courses of English for General Purpose: a study across proficiency levels. Journal of Institute of Modern Languages. 55-80.

Quase, A. (2007). Private University Act and some Records. The Independent. 12.

Rahman, A. M. M. H. (1999). English Language Teaching in Bangladesh: Didactics on the Pragmatics of a Language Teaching Policy. Collected Papers of the International Conference on National and Regional Issues in English Language Teaching: International Perspective. Dhaka: British Council. 5- 32.

Richards, J. C. and Rodgers, T. S. (2001). Approaches and Methods in Language Teaching. Cambridge: Cambridge University Press.

Richards, J. C. (2008). Teaching Listening and Speaking from Theory to Practice. Cambridge: Cambridge University Press.

Richards, J., Platt, J. and Weber, H. (1985). Longman Dictionary of Applied Linguistics. London: Longman.

Ross, (1977). Speech Communication: Fundamentals and Practice. Prentice-Hall: Englewood Cliffs.

Silberstein, S. (1994). Techniques and Resources in Teaching Reading. Oxford: Oxford University Press.

Saha, M. (2008). Teaching 'Listening' as an 'English Language Skill'. Crossings: ULAB Journal of English Studies. Vol. 2, No. 2, 193-206.

Sadat, M. M. M. and Alam, M. M. (2006). Making Both Ends Meet in EFL Speaking Classroom in Bangladesh. The Journal of Social Studies. Vol.1, No. 10, 63-75.

Siddiqui, D. H. G. A. (2009, December 30). Growth and Contribution of Private Universities. The Daily Star. 3.

Ur, P. (1984). Teaching Listening Comprehension.Cambridge:Cambridge University Press.

Venkateswaran, S. (1995). Principles of Teaching English.New Delhi: Vikas Publications.

Wahid, S. (2009). A Paradigm Shift Worth Reckoning. The Daily Star. 2

Wang, H. (2008). Probing EFL Students' Language Skill Development in Tertiary Classrooms.English Language Teaching.Retrieved July 9, 2010 from <http://www.ccsenet.org/journal/index.php/elt/article/view/436/456.

Appendix-1: Questionnaire for the students

(All this question are designed to get the linguistics data; this will be used for research purpose only)

Please answer the following questions

Name:

Educational institute:

No: Semester: Session:

Mobile: Date:

Sex: $\quad$ Roll No: Registration

What is your level of education? : Under-Graduate/Graduate

1. What is the medium of instruction in your English class?
a. English
b. Bangla
c. Mixture of English and Bangla

2. Has the university offered any specific listening course to you?
a. Yes;
b. No

3. Is there any mark allocated for listening skills in your English course outlines?

a. Yes; b. No

4. Do you understand English programmes (BBC, CNN, English movie, serials, reality shows)?

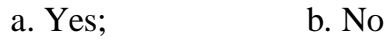


5. Do you need practice to develop your listening skills?
a. Yes;
b. No

6. Are there any activity/activities done in your English classes for listening skills (listening to TV or radio news/ weather/ conversation/ songs etc)?
a. Yes;
b. No

7. Do you think that the content (text) of your classroom activities is from Bangladeshi context?
a. Yes
b. No

8. Have you found the content/material interesting?
a. Yes
b. No

9. Are you motivated to take part in presentation/ role play/group work/pair work in your English classroom?
a. Yes
b. No

10. Do you prefer specific listening course for the development of your listening skill?
a. Yes
b) No

\section{Appendix-2Questionnaire for the Teachers}

(All this question are designed to get the linguistics data; this will be used for research purpose only)

Please answer the following questions:

Full name:

Educational Institute.

Teaching experience:

1. Do you use mixture of English and Bangla medium of instruction in your English class?
a. Yes
b. No

2. Do you think that the universities offer any specific listening course to the students?
a. Yes
b. No

3. Is there any mark allocated for listening skills in your English outlines?
a. Yes
b. No

4. Do you think that students understand English programmes?
a. Yes
b. No

5. Do you think that students need to practice to develop their listening skill?
a. Yes
b. No

6. Are there any activities/activity done in your English classes for listening skill?
a. Yes
b. No

7.Do you think that the content of your classroom activities is from Bangladeshi context?
a. Yes
b. No

8. Do you think that students find the material interesting?
a. Yes
b. No

9. Do you motivate your students to take part in presentation/role play/group work/pair work in your English classroom?
a. Yes
b. No

\section{Copyrights}

Copyright for this article is retained by the author(s), with first publication rights granted to the journal.

This is an open-access article distributed under the terms and conditions of the Creative Commons Attribution license (http://creativecommons.org/licenses/by/4.0/) 